Article

\title{
Reciprocity and the Risk of Rejection: Debate over Sacrifice in the Hebrew Bible
}

\author{
Göran Eidevall(1) \\ Department of Theology, Uppsala University, P.O. Box 511, SE-751 20 Uppsala, Sweden; \\ goran.eidevall@teol.uu.se
}

Received: 15 November 2018; Accepted: 17 December 2018; Published: 19 December 2018

\begin{abstract}
Sacrifice is a central but contested topic in the prophetical literature in the Hebrew Bible. Whereas some texts criticize the sacrificial cult vehemently, other texts express strong support for such a cult. Interestingly, and somewhat paradoxically, a certain writing, such as the book of Jeremiah, may contain both cult-critical prophecies and passages that promote sacrifices. Divergent interpretations of this ancient debate have engendered an intense scholarly debate. Adopting a new approach, informed by sacrifice theories that emphasize the notion of reciprocity, this article refutes the view that prophets like Amos and Jeremiah rejected all sacrifices. Rather, they (that is, the authors of these books) addressed specific situations, or explained specific catastrophes in retrospect. Viewed from this perspective, the cult-critical prophecies, as well as other references to rejected sacrifice, are in fact compatible with a basically positive attitude towards the sacrificial cult.
\end{abstract}

Keywords: reciprocity; rejected sacrifice; prophetic literature; cultic critique

\section{Introduction: Scholarly Debate on Prophetic Attitudes towards Sacrifice}

In earlier exegetical research, a certain group among the religious intermediaries in ancient Israel and Judah were often regarded as prototypical prophets of doom. As such, they were also celebrated as harbingers of "true" monotheism, a new, and more enlightened stage within the history of religions. This group included Amos, Hosea, Isaiah, and Jeremiah (all of them allegedly active in the 8th and the 7 th centuries BCE). According to Julius Wellhausen, Amos was the first spokesman for this radical movement, which denounced the "popular" cult on ethical grounds. (Barton 2007; Clifford 2011, pp. 149-52) Other scholars went even further. They contended that Amos and the other canonical pre-exilic prophets stood for a wholesale rejection of the entire sacrificial cult. Focusing especially on Amos and Jeremiah, because they could be regarded as the most radical critics of the cult, a German exegete, Paul Volz, made an attempt to formulate convincing arguments for the hypothesis that these prophets were against all sacrifices (Volz 1937). According to Volz (1937, pp. 64-72), the following observations support such a conclusion:

(a) The critique delivered by Amos and Jeremiah was not limited to local sanctuaries; it concerned the central, royal sanctuaries in Israel (Bethel) and Judah (Jerusalem);

(b) these two prophets did not advocate religious reforms; presumably, because they wanted to abolish the existing cult altogether;

(c) they idealized Israel's past, especially the time before the conquest of Canaan (Amos 5:25; Jer 7:22-23); presumably, because Israelite religion at this stage remained pure, free from the sacrificial cult, which had "Canaanite" origins and threatened to pervert the worship of the Israelite people;

(d) both Amos and Jeremiah were persecuted by priests (see Amos 7:10-17; Jer 20:1-6); presumably, because they were against temple cult and priestly rituals; 
(e) in some prophecies they used formulations that implied a total rejection of the sacrificial cult.

This view remained influential among biblical scholars until the 1950s. In light of more recent research, however, it stands out as biased, as well as anachronistic. As pointed out by Klawans (2006, pp. 6-9), the approach of Wellhausen and his followers was flawed by its heavy dependence on evolutionism. Especially animal sacrifice was seen as "a relic from a more primitive era". Furthermore, Zevit (2004) has argued (in my opinion, very convincingly) that what he refers to as the "prophet versus priest antagonism hypothesis", a largely Weberian construction, cannot be upheld. The idea that prophets tended to be freelancers, operating outside of temples and other institutions, has largely been abandoned. In his overview of ancient prophecy, covering Mesopotamia and Greece as well as the Hebrew Bible, Martti Nissinen adduces ample evidence indicating that prophetic performances often took place in sanctuaries, and that prophets tended to promote the temple cult (Nissinen 2017, pp. 201-56). One may add that, among biblical scholars subscribing to the view that the so-called classical prophets rejected all sacrifices, an inclination toward anachronistic evolutionism was often coupled with a decidedly Protestant bias. Volz even compared Jeremiah, delivering his temple sermon, with Martin Luther (Volz 1937, p. 63). He maintained that Amos and Jeremiah advocated a new form of worship, centering on the word of God rather than rituals, just like a traditional Protestant service (Volz 1937, p. 79).

One might think that such ideas belong to a distant past within the Hebrew Bible exegesis. However this is not the case. In a relatively recent study, by Thomas Krüger, the pre-exilic prophets are described as forerunners of both the Protestant reformation and the European Enlightenment (Krüger 2006, pp. 53-54). Despite his awareness of the biased character of much earlier scholarship on "the classical prophets of Israel", John Barton contends, similarly, that "it is not necessarily an anachronism to paint them in the colors of Protestant reformers" (Barton 2012, p. 90). According to Barton (2012, pp. 84-92), who refers to the anthropological fieldwork carried out by Mary Douglas, Amos is indeed best described as an anti-ritualist.

It is somewhat surprising, with regard to the weighty counterarguments that have been adduced against it (see above), that this scholarly position persists. One of the main reasons is probably the theory that Amos and Jeremiah were anti-ritualists, which has the capacity to account for the radical and general words of denunciation that we find in some passages in these prophetic books. Conversely, this is the weakness of the most popular alternative theory, according to which the cult-critical prophecies did not target the cult in itself, but the attitude and/or behavior of certain worshippers (Eidevall 2012, pp. 14-23). In the words of Robert Carroll, from his commentary on a text in Jeremiah (Jer 7:21-23), "not sacrifice but those who sacrifice are the object of scorn" (Carroll 1986, p. 216). This may sound reasonable. Evidently, cult-critical prophecies were often grounded in accusations of unethical behavior (see Klawans 2006, pp. 84-89). Further, it is possible that the prophets (or the authors of the prophetic writings) sometimes used hyperbolic language (Bibb 2004). However, as far as I can see, some passages, such as Amos 5:21-24 and Isaiah 1:11-15, declare unambiguously that YHWH (the national god of Israel and Judah) rejects both the sacrifices and those who offer them.

Against this background, I suggest that a new approach is called for. Metaphorically speaking, the task is to navigate between Scylla and Charybdis. On the one hand, one should avoid the anachronistic notion of anti-cultic prophets. On the other hand, one should also avoid interpretations that ignore or explain away the most radically cult-critical formulations found in the prophetic literature. I hope to be able to demonstrate that this is possible. The key, in my opinion, lies in recognizing the fundamental importance of two closely related concepts: Reciprocity and rejection. From the perspective of a reciprocity-oriented understanding of sacrifice, the risk of rejection can be seen as an inevitable aspect of sacrificial cult. I will show that many texts in the Hebrew Bible, also outside the prophetic literature, exhibit an awareness of that risk. However, a discussion of all relevant texts in the prophetic literature would exceed the limits of an article like this. A selection must be made. For reasons stated above, the detailed analysis of prophetic passages will focus on examples from the books of Amos and Jeremiah. According to this emerging scholarly approach, the cult-critical passages, with their words 
of all-encompassing rejection, are in fact compatible with a basically positive view of temple cult, including various forms of sacrificial worship (see also Glaim 2017).

\section{Reciprocity and Rejection}

Traditionally, theories concerning the function of sacrifice have tended to treat this phenomenon either as a gift to the gods, or as a means (sometimes an expiatory means) to establish a relationship (or communion) with the gods. A reciprocity-oriented approach to sacrifice manages to combine these aspects in an ingenious way (Eidevall 2012, pp. 31-41).

In this context, the term reciprocity refers primarily to the sophisticated system of mechanisms at work in social exchange of gifts between human beings (Seaford 1998). As demonstrated by Daniel Ullucci, sacrificial worship can be understood in terms of such reciprocity (Ullucci 2012, pp. 24-27). The same kind of mechanisms are at work, the main difference being that mutual gift-giving takes place within a human-divine relationship. It is worth noting that this type of exchange differs considerably from strictly economic exchange of commodities (van Baal 1976, pp. 165-67; Seaford 1998). To begin with, "reciprocity is voluntary, because, although there are moral and social expectations of requital, there is no 'law' to enforce this, no authority to call upon, except a social norm" (Gudme 2013, p. 23). Further, within such a framework, the relationship can be asymmetrical, and the exchange may appear to be curiously unfair. If one person (typically, the richer or the more powerful of the two) consistently brings more expensive presents, this need not create any problem, however, as long as the mutual gift-giving continues (Ullucci 2012, p. 26). The goal is not to reach a balance, and thereby get rid of burdening debts and obligations. On the contrary, the goal is to establish or uphold a relationship, based on a continuous (ideally, never-ending) exchange of gifts (with Gudme 2013, p. 24).

This is not the place to give a full account of such an approach to sacrifices (see Ullucci 2012, pp. 15-30; Gudme 2013, pp. 21-36). For the purpose of this article, I would like to emphasize one important aspect in particular, namely the risk of rejection. In some situations, we may refuse to accept a gift. Due to the voluntary character of reciprocal exchange, every act of generosity involves risk-taking, "for there is always the possibility that it will not be requited" (Seaford 1998, p. 2). Applying this line of argumentation to the sphere of religion, and referring to several quotations from ancient Greek literature, Ullucci observes that "favor from the gods could never be guaranteed" (Ullucci 2012, p. 28). In other words, according to the logic of reciprocity, someone who approaches a deity with an offering would always run a certain risk of being rejected (with Glaim 2017, p. 126).

\section{Rejected Sacrifice in the Hebrew Bible}

In a pioneering study, Fred Naiden called attention to what he referred to as an "infrequent but important phenomenon" in ancient Greek religion and Hebrew religion, namely rejected sacrifices (Naiden 2006, quote on p. 189). Based on a discussion of examples from Greek sources (including Homer's writings) as well as from the Hebrew Bible, Naiden was able to outline a common pattern. As a rule, the deity would discard both the offering and the accompanying prayer: "The god rejects everything and everyone-sacrifice, request, any prayer, and, most important, the worshipper" (Naiden 2006, p. 195). In most cases, rejection seems to serve as a punitive response to acts of sacrilege or severe disobedience (Naiden 2006, pp. 199-208).

On closer examination, though, rejected sacrifice cannot be said to be a particularly "infrequent" phenomenon in the Hebrew Bible. This is true, even if one chooses to disregard all references to offerings made to deities other than YHWH, such as Baal. As might be expected, such (allegedly) heterodox sacrifices are consistently condemned by biblical writers. As to sacrifices that were destined for but declined by YHWH, Naiden lists only seven cases, usually involving a reference to some kind of ritual or ethical transgression (Naiden 2006, p. 221). However, several examples from the Deuteronomistic History and the prophetic literature are missing in his survey. The following list of biblical references to rejected sacrifice is more comprehensive, but it may nonetheless turn out to be somewhat incomplete: 
Genesis: 4:3-7 (Cain and Abel, see below)

Leviticus: 10:1-3 (Nadab and Abihu)

Numbers: 16:15-32 (Korah and his followers)

1 Samuel: 2:12-3:14 (the sons of Eli) and 15:1-26 (Saul)

1 Kings: 13:1-5 (Jeroboam)

2 Chronicles: 26:16-21 (Uzziah)

Isaiah 1:10-17

Jeremiah: 6:20 and 14:11-12

Hosea: 8:11-13

Amos: 4:4-5 and 5:21-24

Malachi: 1:6-14

Because divine pleasure is often tacitly assumed in the sources, it would be difficult to make a corresponding list with all instances of accepted sacrifice. An exceptionally clear case is found in Gen 8:20-22, where it is expressly stated that YHWH was delighted by Noah's sacrifice, and that this resulted in a divine promise of global protection (see Glaim 2017, pp. 134-35). It is important to keep in mind that relatively rare phenomena may become popular literary motifs, for instance, because they add a dramatic effect. Nonetheless, it remains a fact that, in substantial parts of the Hebrew Bible, explicit rejection of sacrifices is more frequently attested than explicit acceptance.

Judging from the textual evidence, it would be misleading to speak of a widespread notion that sacrifices worked more or less automatically (cf. Hidal 2004, p. 16). On the contrary, numerous biblical texts would seem to presuppose an awareness of the risk of rejection. The following passages from the wisdom literature can serve as illustrative examples: Job 42:7-9; Prov 14:9; 15:8; 21:3; $21: 27$ (see Ernst 1994). In order to underscore the significance of this theme within the Hebrew Bible as a whole, I find it appropriate to elaborate on one of the most famous narratives in the book of Genesis.

Regarding the topic of sacrifice in the Hebrew Bible, it is worth noting that the theme of rejection is there from the very beginning. Sacrifice as a means of worship is mentioned for the first time in Genesis 4, in the story about Cain and Abel. Both bring sacrificial gifts to YHWH, but the outcome is different: "YHWH had regard for (or: Looked with favor on) Abel and his offering, but he disregarded (or: Did not look with favor on) Cain and his offering" (Gen 4:4-5). No reason is stated for the deity's decision (which had fatal consequences).

Why, then, was Cain's sacrifice repudiated? As expected, scholars have propounded various hypotheses. For instance, it could be due to Cain's attitude, or to improper ritual performance (McKeown 2008, pp. 40-41). However, in the absence of textual support, such explanations remain purely hypothetical (with Westermann 1987, p. 32). Based on a close reading of the narrative, it might seem more likely that the rejection had to do with a divine predilection for meat, or blood (thus, e.g., von Rad 1972, p. 104). Whereas Abel, the shepherd, sacrificed animals from his flock, his elder brother Cain, the farmer, brought grain and fruit (Gen 4:2-4). However, the theory that YHWH was known to dislike vegetal offerings cannot find support in any other biblical text. Hence, the mystery has to remain unsolved. As far as I can see, there is no reason to assume that Cain was rejected because of his attitude, or because he had committed any criminal act. Rather, according to the narrative, it is the other way round. The experience of divine (capricious?) disfavor made Cain so furious and envious that he killed his brother (Gen 4:5-8). Interestingly, then, the first biblical story that mentions sacrifice describes it as an extremely risky enterprise (see also Glaim 2017, pp. 130-31).

Arguably, the so-called cult-critical passages in the prophetic literature need to be understood against the background sketched above. Far from representing an extreme or deviant position, these announcements of rejection are based on a notion shared by many biblical authors: One cannot always take divine acceptance of sacrificial gifts for granted. In the next section, I will offer a detailed analysis of a few selected texts from the books of Amos and Jeremiah. 


\section{Cult-Critical and Cult-Affirming Prophecies: Amos and Jeremiah}

\subsection{Amos}

The first text to be considered is Amos 5:21-24, a paradigmatic example of prophetic repudiation of sacrifices. Judging from the literary context, this critique concerns the cult at a temple in the Northern Kingdom (Paul 1991, pp. 188-89), possibly in Bethel (cf. Amos 7:10-17):

21 I hate, I reject your festivals, and I do not delight in your assemblies.

22 Even if you bring me burnt offerings, and your grain offerings, I will not accept them.

I will not even look at the communion sacrifices of your fatlings.

23 Take away from me the noise of your songs!

I do not want to hear the music of your harps.

24 But let justice roll down like waters,

righteousness like an ever-flowing stream. (Amos 5:21-24; from Eidevall 2017a, p. 84)

Clearly, this announcement of divine rejection is both comprehensive and uncompromising. Through his mouthpiece, the prophet, the deity (YHWH) declares that he refuses to accept the three most common types of offerings: The grain offering (vegetables), the burnt offering (meat), and the communion sacrifice (v. 22). Indeed, the divine dislike would seem to concern the cult in its entirety, including major festivals (v. 21) and musical performances (v. 23). On closer examination, however, this text does not condemn sacrifices as such. It does not assert that burning meat from a ritually slaughtered animal on an altar represents a heterodox means of worship, or that it should be considered inferior to prayer or fasting. On the contrary, the rhetoric of this passage presupposes that a functioning sacrificial cult is of paramount importance for the human-divine relationship, and that a breakdown of the cult would have serious consequences for the well-being of the addressees.

This prophecy proclaims relational and situational rejection. It is worth paying attention to the use of pronouns. The formulations used are consistently directed to a certain group of addressees (either a local assembly or the entire nation of Israel at a certain time), pointing to the reciprocal relationship between them and their patron deity: "I reject your festivals ... your assemblies ... your grain offerings ... your fatlings ... your songs ... your harps." Priestly terminology is used throughout (Jeremias 1998, pp. 101-2). One may infer that YHWH would be prepared to accept offerings brought by others. A similar analysis, centering on the relational and situational character of the rejection, can be made of another well-known cult-critical passage, Isa 1:10-17 (Eidevall 2012, pp. 77-88).

In Amos 5, the reason behind the deity's radical rejection is not spelled out in detail. However, in view of the concluding exclamation (v. 24), as well as the literary context (Amos 5:7, 10-12), one may infer that it is connected to accusations of corruption and injustice (see further Eidevall 2017a, pp. 168-69).

A survey of all cultic references in the book of Amos yields the following result: Whereas sanctuaries frequented by the population of the Northern Kingdom are condemned (the addressees are repeatedly advised to avoid such places as Bethel, Dan, and Gilgal; see 4:4-5; 5:4-5; 8:13-14), the cult in Jerusalem is never criticized (Eidevall 2016, pp. 105-14). On the contrary, the book's prologue, in 1:2, implies that the Jerusalem temple served as the abode of YHWH (see also Sweeney 2000, p. 200). This perspective was evident in the book's epilogue, too (9:11-15). Hence, the two decisive factors would seem to be the (alleged) lack of justice, and the choice of cultic site. According to the (retrospective) perspective of the scribes that composed the book of Amos, all of the sanctuaries in the Northern Kingdom were doomed, along with the kingdom itself. In that situation there was no room for reciprocity. Hence, the sacrificial cult had lost its raison d'être.

Probably due to its focus on the downfall of the Northern Kingdom, Israel, in the 720s BCE, the book of Amos does not contain any prophecy that affirms the sacrificial cult (with Glaim 2017, p. 139). 


\subsection{Jeremiah}

The situation is markedly different in the book of Jeremiah, which both laments and sanctions the destruction of Jerusalem and its temple in 586 BCE. Here, harsh announcements of rejection and oracles that promote sacrificial worship are juxtaposed. An example of the former category is found in Jer 6:20:

What is this to me-frankincense that comes from Sheba, and sweet cane from a distant land?

Your burnt offerings are not acceptable, and your sacrifices do not please me. (Jer 6:20)

Formally speaking, this utterance looks like an inverted priestly formula, declaring that the offerings have been accepted by the deity (Holladay 1986, p. 223). The appropriate technical terms are employed, but they have been negated. Thus, the offerings "are not acceptable ... do not please me." However, this is not a general repudiation of sacrificial cult per se (contra Fretheim 2002, p. 125). The scope is best described as total (no offerings seem to be exempted), yet limited to a specific situation. Rather than formulating a general view on sacrifices, this prophecy conveys a severe threat, in the midst of a national crisis. In the words of Aaron Glaim, "the incense and sacrifices of the Judeans can neither avert nor suspend Yahweh's judgments" (Glaim 2017, p. 146).

By means of the consistent use of second person plural pronouns the notion of (threatened) reciprocity is evoked, also in this case (cf. Amos 5:22-23 above). The very relationship between the deity and the worshippers is at stake. In the immediately preceding statement, the people are accused of neglecting divine instruction: "They have rejected my teaching (tôrâtî)" (Jer 6:19). This recalls Samuel's sinister message for King Saul, whom he had accused of disobeying the deity's instructions: "Because you have rejected the word of YHWH, he has rejected you from being king" (1 Sam 15:23). In both cases, the underlying logic appears to be as follows: Because the addressees have rejected YHWH's Torah, which regulates the human-divine relationship, YHWH has resolved to reject any offerings or requests that come from them (similarly also Lundbom 1999, p. 438).

The prophecy in Jer 14:11-12 can be seen as even more radical, as regards the implications for communication and interaction between human worshippers and their God:

YHWH said to me: "Do not pray for the welfare of this people. When they fast, I am not going to listen to their cry, and when they offer burnt offering and grain offering, I am not going to accept them. Instead, I am going to destroy them by the sword, by famine, and by pestilence." (Jer 14:11-12)

According to this oracle, all types of official worship have become inefficacious. In the prevailing situation, it is announced, YHWH will disregard the people's attempts to reach him. In v. 12, both animal sacrifices and vegetal offerings are mentioned. Hence, there can be no doubt that the entire sacrificial cult is rejected. Further, YHWH declares that he will refuse to listen to any prayers for help, such as the lament cited in 14:7-9. Jer 14:11-12 is by far the most all-inclusive of all the cult-critical passages in the prophetic books. In comparison with such paradigmatic texts as Amos 5:21-24 and Isa 1:11-15, this prophecy adds one communal cultic activity to the list, namely fasting (cf. Jer 36:9). As if that was not enough, it is declared that prophetic intercession is prohibited. In other words, all channels are blocked. The addressees cannot reach YHWH. What remains is one-way communication in the form of prophetic proclamations of the divine will.

Although the message is clear, it is difficult to make sense of Jer 14:11-12 as public prophecy. From a rhetorical point of view it appears to be puzzlingly pointless, or even counterproductive, if one assumes that these words were spoken before the national catastrophe that occurred in 586 BCE. Why would a YHWH prophet discourage all cultic worship of this deity? Why would anyone want to be loyal to a god who refuses to avert a disaster that threatens to destroy his worshippers? According to my analysis, the key to interpretation lies in recognizing that this passage, like many others in the prophetic literature, was formulated in retrospect. The real addressees are the first readers of the book of Jeremiah, during or after the exile (with McKane 1986, p. 328). From their perspective, Jer 14:11-12 
provides answers to a fundamental theological question that such a traumatic event as the destruction of Jerusalem and temple would have given rise to: How could it happen, despite all prayers and sacrifices? This text exonerates YHWH. The national patron god was not unable to protect his people. Rather, he punished the people for their disloyalty. At the same time, the significance of (legitimate) cultic activities is actually underscored by this text (with Glaim 2017, p. 147). In order to achieve these two goals, rehabilitating the people's trust in YHWH and resuscitating their confidence in the communal cult, the author of Jeremiah 14 had to construct this type of prophecy, allegedly proclaimed before the disaster.

In other words, this rejection of the cult is linked to a basically positive view of the cult, including various types of sacrificial worship. The readers are reassured that the pre-exilic cult was not ineffective in itself. Rather, all human-divine reciprocity broke down some years before $586 \mathrm{BCE}$, as a direct consequence of the people's iniquity (see 14:10). Because YHWH might have been appeased by offerings and prayers and fasting, he had to discontinue or reject all such cultic activities. Likewise, prophetic intercession was prohibited, precisely because it was considered potentially efficacious.

The hopeful prediction in Jer 17:26 provides a sharp contrast to the preceding examples, since it speaks positively about sacrifices without implying any risk of rejection:

They will come from the towns of Judah and from the surroundings of Jerusalem, from the land of Benjamin and the lowland, from the hill country and the Negev, bringing burnt offering, communion sacrifice, grain offering, and incense, bringing thank offering to the house of YHWH. (Jer 17:26)

This utterance is part of a longer passage, comprising Jer 17:19-27. Within the literary context, this prophecy is presented as a speech delivered by Jeremiah, before the disaster that occurred in 586 BCE, but it makes excellent sense as a retrospective reflection of that event (Carroll 1986, pp. 367-69). Purporting to provide a key to the history of Judah, this passage attempts to answer some questions that would have been relevant in the post-exilic period, in the era of the Second Temple: Why did YHWH abandon his sanctuary? How could he let it be destroyed by the Babylonian army? How can we be sure that this will not happen again?

Interestingly, this prophecy claims that it is possible to avoid such a tragic scenario. It envisions an almost utopian future as a realistic alternative. The preconditions are clearly stated: "You must obey me, says YHWH, and bring no load through the gates of this city on the Sabbath day" (Jer 17:24). Thus, according to this text, a strict Sabbath observance, something that was sadly neglected by previous generations (17:22-23), would guarantee a state of never-ending prosperity (17:24-26). Conversely, all kinds of misfortunes, including rejected sacrifices, are here explained as divine punishments for the people's failure to keep the Sabbath.

Interestingly, sacrificial worship is not described as an obligation in Jeremiah 17 (but Sabbath observance is). The emphasis is not on the effects of bringing gifts to YHWH. A flourishing cult is rather seen as a gift from YHWH, as a reward for keeping the most important commandments. Expressing gratitude appears to be the main function of the offerings, and divine acceptance appears to be taken for granted (as long as the worshippers keep the Sabbath day holy). In a similar vein, the prophecy in Jer 33:10-11 associates sacrificial worship primarily with joy: "The voice of joy and the voice of gladness ... while they are bringing thank offerings to the house of YHWH" (v. 11). Finally, the prophecy in Jer 33:18 promises that "the Levitical priests will never lack someone standing before me, offering burnt offerings, burning grain offerings, and preparing sacrifices, every day." According to this text, from the Second Temple period (Holladay 1989, pp. 229-30), uninterrupted sacrificial cult, which cannot be rejected, is an essential part of the ideal future (see further Eidevall 2017b, pp. 164-66).

It is an intriguing fact that the book of Jeremiah contains prophecies with strongly contrasting perspectives on sacrifice. This is probably not due to an editorial intention to include different views that were expressed in an on-going debate. Conflicting prophetic messages were seen as a major problem within the Jeremiah tradition (see Jeremiah 28). How, then, could this conspicuous 
juxtaposition of cult-critical and cult-supportive prophecies be explained? In my opinion, the best solution has been indicated by Lena-Sofia Tiemeyer, in a pivotal study of shifting attitudes towards priests in the book of Jeremiah (Tiemeyer 2009). She discovered that there is a chronological division that explains why some priests are criticized and others are not. Whereas passages speaking about the pre-exilic situation "betray a critical disposition towards the priests and / or the cult", those texts that refer to the present situation or the future (that is, to the cult in the Second Temple) tend to "view the priests and/or the cult positively" (Tiemeyer 2009, p. 155). A recent systematic investigation of all prophecies in the book of Jeremiah that deal with sacrifice has confirmed Tiemeyer's observations (Eidevall 2017b). Hence, I suggest that both the cult-critical and the cult-affirming passages can, despite their differing perspectives, be read as expressions of a consistent ideology, linked to circles that promoted the cult in the Second Temple (thus also Glaim 2017, pp. 148-49). Whereas passages that condemn sacrifices (Jer 6:20 and 14:11-12) always refer to the past (that is, the pre-exilic cult), the passages that support sacrificial worship (Jer 17:19-27 and 33:10-11,18) always refer to the present or the future.

\section{Concluding Remarks}

In this article, I have argued against the view that the classical prophets in Israel and Judah were against all sacrifices. According to my analysis, they did not advocate the abolition of the sacrificial cult. To be more precise, I have attempted to demonstrate that the authors of these prophetic writings did not express such an anti-cultic view. Rather, they exploited the awareness of a certain risk of rejection, which can be seen as a corollary of the reciprocal character of sacrificial worship, for their own rhetorical and ideological purposes. Thus, it was maintained that some divine declarations of large-scale rejection of the people's sacrifices served as retrospective explanations of national disasters. Most importantly, the cult-critical passages in the prophetic literature are always connected to a specific site or situation. Therefore, in the book of Amos, radical rejection of the cult performed in one temple (for instance, Bethel) would seem to be perfectly compatible with promotion of the cult of another temple (Jerusalem). Similarly, for the authors of the book of Jeremiah, there was no contradiction between condemnation of sacrificial cult in the past and enthusiastic support of sacrificial cult in their own time.

According to the analysis presented in this article, all the diverse statements on cultic offerings that one can find in the books of Amos and Jeremiah (and, by extension, in the prophetic literature as a whole) attest to the centrality of sacrifice in the conceptual world of the biblical writers. If sacrificial worship was considered unnecessary, certain texts that proclaim radical rejection (such as Amos 5:21-24 and Jer 6:20) would lose much of their rhetorical force. Similarly, if they did not regard sacrificial worship as an essential part of a well-functioning human-divine relationship, the prophetic writers would not have included this in their depictions of a utopian future.

Funding: This research received no external funding.

Conflicts of Interest: The author declares no conflict of interest.

\section{References}

Barton, John. 2007. Wellhausen's Prolegomina to the History of Israel: Influences and Effects. In Idem, Old Testament: Canon, Literature and Theology: Collected Essays of John Barton. Aldershot: Ashgate.

Barton, John. 2012. The Theology of the Book of Amos. In Old Testament Theology. Cambridge: Cambridge University Press.

Bibb, Bryan D. 2004. The Prophetic Critique of Ritual in Old Testament Theology. In The Priests in the Prophets: The Portrayal of Priests, Prophets and Other Religious Specialists in the Latter Prophets. Edited by Lester L. Grabbe and Alice Ogden Bellis. Journal for the Study of the Old Testament Supplement Series 408; London: T \& T Clark, pp. 31-43.

Carroll, Robert P. 1986. Jeremiah. London: SCM Press. 
Clifford, Hywel. 2011. Amos in Wellhausen's Prolegomina. In Aspects of Amos: Exegesis and Interpretation. Edited by Anselm C. Hagedorn and Andrew Mein. Library of Hebrew Bible/Old Testament Studies 536. New York: T \& T Clark, pp. 141-56.

Eidevall, Göran. 2012. Sacrificial Rhetoric in the Prophetic Literature of the Hebrew Bible. Lewiston: Edwin Mellen.

Eidevall, Göran. 2016. A Farewell to the Anticultic Prophet: Attitudes towards the Cult in the Book of Amos. In Priests and Cult in the Book of the Twelve. Edited by Lena-Sofia Tiemeyer. Ancient Near Eastern Monographs 14. Atlanta: SBL Press, pp. 99-114.

Eidevall, Göran. 2017a. Amos: A New Translation with Introduction and Commentary. Anchor Yale Bible $24 \mathrm{G}$. New Haven: Yale University Press.

Eidevall, Göran. 2017b. Prophetic Cult-Criticism in Support of Sacrificial Worship? The Case of Jeremiah. In Sacrifice, Cult, and Atonement in Early Judaism and Christianity: Constituents and Critique. Edited by Henrietta L. Wiley and Christian A. Eberhart. Resources for Biblical Study 85. Atlanta: SBL Press, pp. 151-67.

Ernst, Alexander B. 1994. Weisheitliche Kultkritik: Zu Theologie und Ethik des Sprüchebuchs und der Prophetie des 8. Jahrhunderts. Biblisch-theologische Studien 23. Neukirchen-Vluyn: Neukirchener.

Fretheim, Terence E. 2002. Jeremiah. Macon: Smith \& Helwys.

Glaim, Aaron. 2017. "I Will Not Accept Them": Sacrifice and Reciprocity in the Prophetic Literature. In Sacrifice, Cult, and Atonement in Early Judaism and Christianity: Constituents and Critique. Edited by Henrietta L. Wiley and Christian A. Eberhart. Resources for Biblical Study 85. Atlanta: SBL Press, pp. 125-49.

Gudme, Anne Katrine de Hemmer. 2013. Before the God in this Place for Good Remembrance: A Comparative Analysis of the Aramaic Votive Inscriptions from Mount Gerizim. Beihefte zur Zeitschrift für die alttestamentliche Wissenschaft 441. Berlin: De Gruyter.

Hidal, Sten. 2004. When and Why Is a Sacrifice Rejected? A Comparison between Homer and the Old Testament. In Dais philesistephanos: Studies in Honour of Professor Staffan Fogelmark. Edited by Pär Sandin and Marianne Wifstrand Scheibe. Uppsala: Dahlia Books, pp. 11-18.

Holladay, William L. 1986. Jeremiah 1. Hermeneia. Philadelphia: Fortress.

Holladay, William L. 1989. Jeremiah 2. Hermeneia. Philadelphia: Fortress.

Jeremias, Jörg. 1998. The Book of Amos: A Commentary. Translated by D. W. Stott. Old Testament Library. Louisville: Westminster John Knox.

Klawans, Jonathan. 2006. Purity, Sacrifice, and the Temple: Symbolism and Supersessionism in the Study of Ancient Judaism. Oxford: Oxford University Press.

Krüger, Thomas. 2006. Erwägungen zur prophetischen Kultkritik. In Die unwiderstehliche Wahrheit: Studien zur alttestamentlichen Prophetie. Edited by Rüdiger Lux and Ernst-Joachim Waschke. Arbeiten zur Bibel und ihrer Geschichte 23. Leipzig: Evangelische Verlagsanstalt, pp. 37-55.

Lundbom, Jack. 1999. Jeremiah 1-20: A New Translation with Introduction and Commentary. Anchor Bible 21A. New York: Doubleday.

McKane, William. 1986. Jeremiah. Volume 1. International Critical Commentary. Edinburgh: T \& T Clark.

McKeown, James. 2008. Genesis. The Two Horizons Old Testament Commentary. Grand Rapids: Eerdmans.

Naiden, Fred S. 2006. Rejected Sacrifice in Greek and Hebrew Religion. Journal of Ancient Near Eastern Religions 6: 189-223. [CrossRef]

Nissinen, Martti. 2017. Ancient Prophecy: Near Eastern, Biblical, and Greek Perspectives. Oxford: Oxford University Press.

Paul, Shalom. 1991. Amos. Hermeneia. Philadelphia: Fortress.

Seaford, Richard. 1998. Introduction. In Reciprocity in Ancient Greece. Edited by Christopher Gill, Norman Postlethwaite and Richard Seaford. New York: Oxford University Press, pp. 1-12.

Sweeney, Marvin A. 2000. The Twelve Prophets. Volume 1. Hosea, Joel, Amos, Obadiah, Jonah. Berit Olam. Collegeville: Michael Glazier.

Tiemeyer, Lena-Sofia. 2009. The Priests and the Temple Cult in the Book of Jeremiah. In Prophecy in the Book of Jeremiah. Edited by Hans M. Barstad and Reinhard G. Kratz. Beihefte zur Zeitschrift für die alttestamentliche Wissenschaft 388. Berlin: De Gruyter, pp. 233-64.

Ullucci, Daniel C. 2012. The Christian Rejection of Animal Sacrifice. Oxford: Oxford University Press.

van Baal, Jan. 1976. Offering, Sacrifice, and Gift. Numen 23: 161-78. [CrossRef]

Volz, Paul. 1937. Die radikale Ablehnung der Kultreligion durch die alttestamentlichen Propheten. Zeitschrift für systematische Theologie 14: 63-85. 
von Rad, Gerhard. 1972. Genesis, rev. ed. Translated by John H. Marks. London: SCM Press. First published 1961. Westermann, Claus. 1987. Genesis: A Practical Commentary. Translated by David E. Green. Grand Rapids: Eerdmans.

Zevit, Ziony. 2004. The Prophet versus Priest Antagonism Hypothesis: Its History and Origin. In The Priests in the Prophets: The Portrayal of Priests, Prophets and Other Religious Specialists in the Latter Prophets. Edited by Lester L. Grabbe and Alice Ogden Bellis. Journal for the Study of the Old Testament Supplement Series 408; London: T \& T Clark, pp. 189-217. 